\title{
SCHIZANTHINE X, A NEW ALKALOID FROM SCHIZANTHUS GRAHAMII
}

\author{
ORLANDO Muñoz,* \\ Universidad de Chile, Facultad de Ciencias, Departamentu de Quimica. Casilla 53, Santiago, Chile
}

RUdOlf HARTMANN, and Eberhard Breitmaier

Institut für Organische Chemie der Universität Bunn. Gerbard-Domagk-Str. 1, D-5300 Bonn, Gernaany

\begin{abstract}
A new dimeric alkaloid 1 has been isolated from Schizanthus grahamii and its structure determined by spectroscopic methods.
\end{abstract}

Grahamine, an unusual tropane alkaloid containing a cyclobutane tricarboxylic acid as a central partial structure, was recently isolated from Schizanthus grabamii Gill (Salpiglossidae) and identified (1). This and other earlier chemical studies of the Schizantbus (2-5) have shown that this genus accumulates a number of tropane-derived alkaloids and may, therefore, be considered a typical member of the Solanaceae. We are here reporting the structure determination of schizanthine $X[\mathbf{1}\}$, a new tropanol mesaconic acid di-ester, similar to other $3 \alpha, 6 \beta$-di-ester tropane derivatives previously isolated from $S$. grabamii (5).

The ${ }^{~} \mathrm{H}$-nmr data of this compound are given in Table 1. The signals of diagnostic value are: (a) the chemical shifts and multiplicity of the olefin protons of the acids; (b) the positions and multiplicity of the skeletal protons at the point of attachment of the ester moiety to the tropane nucleus; and (c) the number of protons for each signal in the spectrum (6).

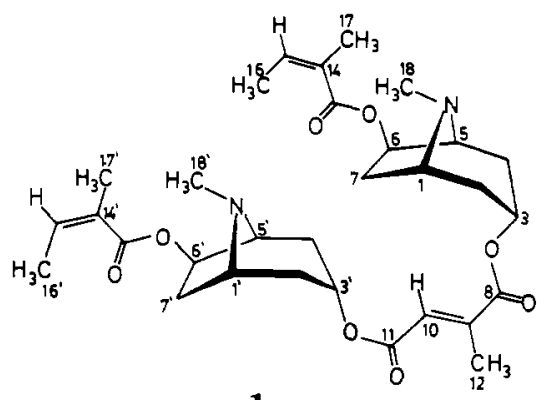

Accordingly, the signal at $\delta 6.79$ $(1 \mathrm{H}, \mathrm{q}, J=1.7 \mathrm{~Hz})$ indicated the presence of mesaconic acid, and the two-proton multiplet centered at $\delta 6.01$ indicated that of two angelic acid residues $\left(2 \mathrm{H}, \mathrm{m}, J_{16}=7.5, J_{17}=1.6 \mathrm{~Hz}\right)$. These assignments were corroborated by additional absorptions for the Me-12 of mesaconic acid at $\delta 2.33\left(3 \mathrm{H}, \mathrm{d}, J_{10}=\right.$ $1.7 \mathrm{~Hz}$ ) and for the $\mathrm{Me}-16,-16^{\prime}$ and $\mathrm{Me}$ $17,-17^{\prime}$ of angelic acid (Table 1) at $\delta$ $2.07(6 \mathrm{H}, \mathrm{d}, J=7.5 \mathrm{~Hz})$ and $1.91(6 \mathrm{H}$, $\mathrm{d}, J=1.6 \mathrm{~Hz}$ ), respectively.

The ${ }^{1} \mathrm{H}$-nmr spectrum of this compound also contained two overlapping two-proton triplets at $\delta 5.0$ and 5.12 , which are typical tropanol nucleus $\mathrm{H}-3$ and $\mathrm{H}-3^{\prime}$ absorptions and show that two such units are present in 1 $\left(\mathrm{C}_{31} \mathrm{H}_{44} \mathrm{O}_{8} \mathrm{~N}_{2}\right)$, linked through $\mathrm{C}-3$. The attachment of the other ester residue at C-6 was shown by the characteristic $\mathrm{H}-6$ and $\mathrm{H}-\mathrm{G}^{\prime}$ multiplets (dd) at $\delta 5.47$ and 5.51 , respectively. These assignments were confirmed by the ${ }^{1} \mathrm{H}-\mathrm{nmr}$ spectrum of $\mathbf{1}$ taken in $\mathrm{C}_{6} \mathrm{D}_{6}$ (Table 1 ), which separated a number of overlapping signals in the $\mathrm{CDCl}_{3}$ spectrum.

The ester linkages to the tropane residue were determined by correlation of the skeletal and acyl protons to the corresponding ester carbonyl groups in 2D long-range ${ }^{13} \mathrm{C}-{ }^{1} \mathrm{H}$ chemical shift correlation experiments. Thus, the angelate carbonyl groups at $\delta 167.70$ and 167.59 showed a strong correlation with signals at $\delta 6.01$ for the $\mathrm{H}-15$ and a weak correlation with a signal at $\delta 5.47$ corres- 
TABLE 1. ' $\mathrm{H}-\mathrm{nmr}(400 \mathrm{MHz})$ and ${ }^{1} \mathrm{C}-\mathrm{nmr}(100.5 \mathrm{MHz})$ Data of Schizanthine X [1] (values from TMS).

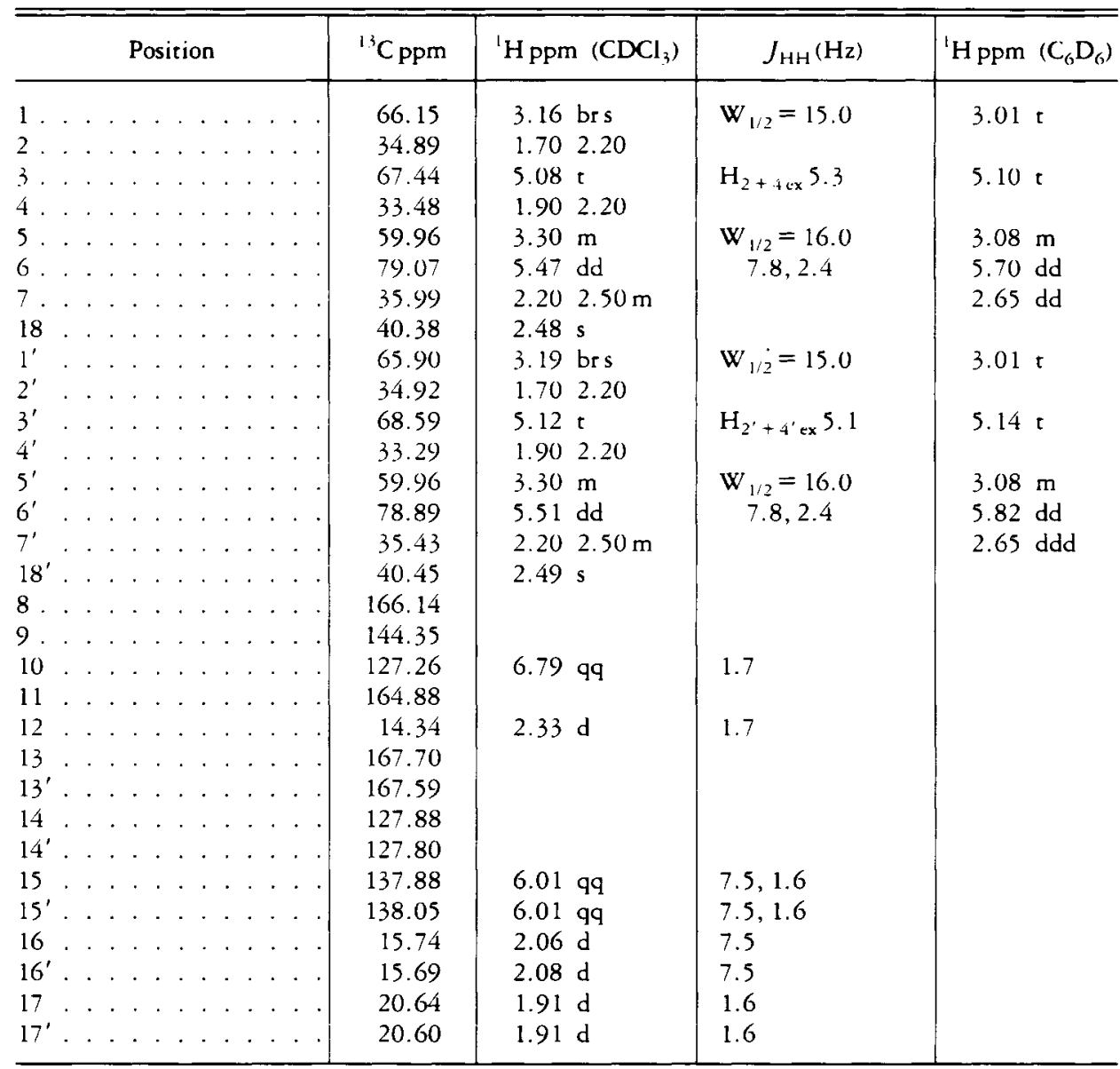

ponding to $\mathrm{H}-6$ (and $\mathrm{H}-\mathrm{G}^{\prime}$ ) of the tropane nucleus. The carbonyl carbons of mesaconic acid at $\delta 164.8$ and 166.14 showed strong correlations with the signal at $\delta 6.79(\mathrm{H}-10)$ and weak correlation with the signals at $\delta 5.08$ and 5.12 for $\mathrm{H}-3$ (and $\mathrm{H}-3^{\prime}$ ) of the tropane nucleus, thereby establishing the sequence of the five molecular subunits.

Eims of 1 showed the well-established fragmentation pattern of 3.6-diacyloxytropane esters $(6,7)$, while the relative intensity of the ions at $m / z 238,222$, 138 , and 122 agrees with the proposed structure: hreims gave $\mathrm{m} / \mathrm{z} 572.3070[\mathrm{M}]^{+}$ (calcd for $\mathrm{C}_{31} \mathrm{H}_{44} \mathrm{O}_{8} \mathrm{~N}_{2}, \quad 572.3043$ ). The assignment of the ${ }^{13} \mathrm{C}$-nmr spectrum was based on $\mathrm{C}-\mathrm{H}$ correlation experiments and comparison with the val- ues of related alkaloids reported in the literature (4-6).

When schizanthine $\mathrm{X}$ was hydrolyzed, (+)-(3R,6R)-tropane-3 $\alpha, 6 \beta$-diol was obtained and identified by comparison with an authentic sample (5), thus defining the absolute configuration of 1 .

\section{EXPERIMENTAL}

Plant material. - The plant was collected in November 1982 in the Cuarta Región in Rengo province, Chile, and a voucher specimen is lodged with the Facultad de Ciencias Herbarium, Universidad de Chile, Santiago.

ISOLATION OF SCHIZANTHINE X.-Airdried and finely powdered leaves of $S$. grahamii $(8.1 \mathrm{~kg})$ were extracted and separated as described previously (4).

Schizanthine $X[\mathbf{1}\}$. Colorless oil (210 mg): $[\alpha]^{25} \mathrm{D}-20^{\circ}(\mathrm{EtOH}, c=0.92)$; ir $\max \left(\mathrm{CHCl}_{3}\right)$ 
$\mathrm{cm}^{-1} 2940,1740,1730,1700,1640,1240 ;{ }^{1} \mathrm{H}$ nmr see Table $1 ;{ }^{1} \mathrm{C} \mathrm{nmr}$ see Table 1; eims $\mathrm{m} / \mathrm{z}$ (rel. int.) [M] ${ }^{+} 572(2), 352$ (1), 279 (4), 238 (14), 222 (14), $193(14), 180(3), 175(5), 167$ (26), $154(12), 139(9), 138(25), 137(14), 127$ (14), 123(17), $122(35), 121(32), 113(32), 112$ (26), $111(40), 110(23), 94(100), 91(16)$; hrms $m / z[M]^{+} 572.3070$ (calcd for $\mathrm{C}_{31} \mathrm{H}_{44} \mathrm{O}_{8} \mathrm{~N}_{2}$, $572.3043)$.

HYDROLYSIS OF 1.-An $\mathrm{H}_{2} \mathrm{O}-\mathrm{ErOH}$ (1:1) solution $(10 \mathrm{ml})$ of 1 (40 mg) and $\mathrm{Ba}(\mathrm{OH})_{2}(150$ $\mathrm{mg}$ ) was refluxed for $24 \mathrm{~h}$ and worked up as described (5) to yield, after sublimation, (+)(3R,6R)-tropane-3 $\alpha, 6 \beta$-diol (19.5 mg): $[\alpha]^{25} \mathrm{D}$ $+20.3^{\circ}(\mathrm{EtOH}, i=0.61)\left[\right.$ lit. $\left.(8)+24.0^{\circ}\right]$.

\section{ACKNOWLEDGMENTS}

We thank Dr. Angel Guerrero of the CSIC, Barcelona, Spain, for the eims data. Financial support from the DTI, Universidad de Chile, is gratefully acknowledged.

\section{LITERATURE CITED}

1. R. Hartmann, A. San-Martín, O. Muñoz, and E. Breitmaier, Angew. Chem., Int. Ed. Engl., 29, 385 (1990).

2. A. San-Martín, J. Rovirosa, V. Gambaro, and M. Castillo, Pbytochemistry, 19, 1007 (1980).

3. V. Gambaro, C. Labbé, and M. Castillo, Phytocbemistry, 22, 1838 (1983).

4. A. San-Martín, C. Labbé, O. Muñoz, M. Castillo, M. Reina, G. de la Fuente, and A.G. González, Pbytocbemistry, 26, 819 (1987).

5. G. de la Fuente, M. Reina, O. Muñoz, A. San-Martin, and P.J. Girault, Heterocycles, 27, 1887 (1988).

6. O. Muñoz, "Alcaloides del tropano de Sibizanthus pinnatus $y$ de Scbizantbus grabamii," Ph.D. Thesis, Universidad de La Laguna, Spain, 1986.

7. M. Lounasmaa, in: "The Alkaloids." Ed. by A. Brossi, Academic Press, New York, 1988, Vol. 33, p. 61.

8. G. Fodor and O. Kovacs, J. Chem. Sor. C, 2341 (1973).

Received 11 May 1990 